\title{
Pertumbuhan Tanaman Pisang Kepok (Musa paradisiaca L.) pada Berbagai Konsentrasi BAP Secara In Vitro
}

\author{
(Plant Growth Kepok Banana (Musa paradisiaca L.) at Various \\ Concentrations of BAP In Vitro)
}

\author{
Zarmiyeni $^{1)}$, Mahdiannoor ${ }^{2)} \&$ Lisa $^{3)}$ \\ Program Studi Agroteknologi, Sekolah Tinggi Ilmu Pertanian Amuntai \\ ${ }^{1)}$ zarmiyenilg@gmail.com \\ ${ }^{2)}$ mahdi_186@yahoo.com \\ ${ }^{3)}$ lisa@gmail.com
}

\begin{abstract}
ABSTRAK
Pisang salah satu komoditas hortikultura yang sangat populer di dunia karena rasanya lezat, harga relatif murah dan memiliki nilai gizi cukup tinggi. Produksi tanaman pisang di Kabupaten Hulu Sungai Utara masih tergolong rendah karena hanya dibudidayakan dalam skala kecil dan tidak tersedianya bibit unggul. Untuk mengatasi kendala tersebut maka perlu dilakukan perbanyakan dengan menggunakan kultur jaringan. ZPT yang sering digunakan untuk merangsang terbentuknya tunas pada kultur in vitro tanaman pisang adalah sitokinin seperti BAP. Sitokinin dalam kultur in vitro mempunyai dua peran penting yaitu merangsang pembelahan sel serta pembentukan dan perbanyakan tunas aksilar dan tunas adventif. Tujuan dari penelitian ini yaitu mendapatkan (i) pengaruh pemberian berbagai konsentrasi BAP terhadap pertumbuhan tanaman pisang kepok secara in vitro. (ii) konsentrasi BAP terbaik untuk pertumbuhan tanaman pisang kepok secara in vitro. Penelitian ini dilaksanakan di Laboratorium kultur jaringan STIPER Amuntai pada bulan April 2013 sampai dengan bulan Agustus 2013 dengan menggunakan Rancangan Acak Lengkap (RAL) faktor tunggal dengan 5 perlakuan dan 4 kali ulangan, sehingga terdapat 20 satuan percobaan. Setiap satuan percobaan terdiri dari 2 eksplan sebagai sampel. Faktor yang diuji adalah berbagai konsentrasi BAP yaitu $b_{1}: 2 \mathrm{mg} / \mathrm{l}, b_{2}: 3 \mathrm{mg} / \mathrm{l}, b_{3}: 4$ $\mathrm{mg} / \mathrm{l}, b_{4}: 5 \mathrm{mg} / \mathrm{l}$ dan $b_{5}: 6 \mathrm{mg} / \mathrm{l}$. Hasil penelitian menunjukkan bahwa persentase tumbuh, persentase terbentuknya tunas, persentase terbentuknya akar, jumlah tunas dan jumlah daun tidak berpengaruh pada perlakuannya.
\end{abstract}

Kata Kunci: : Pisang, sitokinin, BAP, kepok, in vitro.

\section{ABSTRACT}

Bananas are one of the horticultural commodities is very popular in the world because it was delicious, the price is relatively cheap and have high nutritional value. Production of banana plants in Hulu Sungai Utara still relatively low because only bananas cultivated on a small and not available the procurement of seeds. To overcome these obstacles do necessary aside propagated using tissue culture techniques. ZPT which are often used to stimulate the formation of shoots in vitro culture banana is cytokinin as BAP. Cytokines in vitro culture has two important roles that stimulate cell division and the formation and propagation of axillary buds and adventitious buds, but the optimum levels of cytokines that can inhibit the growth and root formation. The purpose of this study is to get (i) the effect of various concentrations of BAP on plant growth kepok banana in vitro, (ii) the best BAP concentration for plant growth kepok banana in vitro. This research was conducted in tissue culture laboratory STIPER Amuntai in April 2013 to August 2013 using a completely randomized design (CRD) single factor with 5 treatments and 4 replications, so there are 20 experimental units. Each experimental unit consisted of 2 explants as a sample. Factors that are tested various concentrations of BAP are $b_{1}: 2 \mathrm{mg} / l, b_{2}: 3$ $\mathrm{mg} / \mathrm{l}, b_{3}: 4 \mathrm{mg} / \mathrm{l}, \mathrm{b} 4: 5 \mathrm{mg} / \mathrm{l}, \mathrm{b} 5: 6 \mathrm{mg} / \mathrm{l}$. The results showed that percentage grows, the percentage of shoot formation, root formation percentage, number of shoots and number of leaves had no effect on treatment.

Keywords : Banana, cytokinin, BAP, kapok, in vitro. 


\section{PENDAHULUAN}

Pisang merupakan komoditas buah tropis yang sangat populer di dunia karena rasanya lezat, harga relatif murah dan memiliki nilai gizi yang cukup tinggi (Sunarjono, 2002 dalam Rainiyati et. al., 2009). Disamping itu pisang juga dimanfaatkan untuk kerajinan rakyat (Luqman, 2012).

Menurut Dinas Pertanian Tanaman Pangan dan Hortikultura Kabupaten Hulu Sungai Utara (2012) produksi tanaman pisang di Kabupaten Hulu Sungai Utara masih tergolong rendah karena hanya dibudidayakan dalam skala kecil karena tidak tersedianya bibit unggul. Data produksi tanaman pisang di Kabupaten Hulu Sungai Utara, untuk mengatasi kendala tersebut maka tanaman pisang selain dari anakan juga diperbanyak dengan menggunakan teknik kultur jaringan tanaman (Priyono et.al., 2000 dalam Surono \& Himawan, 2010). Media Murashige and Skoog (MS) telah banyak digunakan sebagai media dasar dalam kultur jaringan (Evans, Sharp, Ammirato, and Yamada, 1983 dalam Sitohang, 2006). Media dasar masih memerlukan penambahan ZPT atau ekstrak organik untuk mempengaruhi arah perkembangan eksplan (Sitohang, 2006).

ZPT yang sering digunakan untuk merangsang terbentuknya tunas pada kultur in vitro tanaman pisang adalah BAP (Wetherell, 1982 dalam Surono \& Himawan, 2010). BAP berperan dalam regulasi pembelahan sel, deferensiasi pertumbuhan jaringan dan organ serta biosintesa klorofil (Murthy et. al., 1995 dalam Luqman, 2012).

Berdasarkan hal tersebut, maka telah dilakukan penelitian tentang pertumbuhan tanaman pisang kepok (Musa paradisiaca L.) pada berbagai konsentrasi BAP secara in vitro.

Tujuan dari penelitian ini yaitu (i) mendapatkan pengaruh pemberian berbagai konsentrasi BAP terhadap pertumbuhan tanaman pisang kepok secara in vitro dan (ii) mendapatkan konsentrasi BAP terbaik untuk pertumbuhan tanaman pisang kepok

\section{METODE PENELITIAN}

Penelitian ini dilaksanakan di Laboratorium kultur jaringan STIPER Amuntai pada bulan April - Agustus 2013. Bahan-bahan yang digunakan dalam penelitian ini adalah Media MS Basil Medium w/vitamin, Eksplan dari bonggol pisang kapok, ZPT BAP dan IBA, Alkohol $70 \%$, Fungisida topsin, Klorok, Spritus, Aquades steril, Sukrosa, Agar-agar, Aluminium foil, $\mathrm{NaOH}$ dan $\mathrm{HCl}$.

Alat-alat yang digunakan dalam penelitian ini adalah Laminar Air Flow Cabinet (LAFC), autoklaf, kompor gas, botol kultur, erlenmeyer, petridish, gelas ukur, scalpel, gelas beker, pinset, hotplate stirrer, timbangan analitik ohaous, pipet (volume dan tetes), kertas lakmus, lampu bunsen, tissue, sprayer, ember, sikat botol, oven, kulkas, panci dandangan, batang pengaduk, sendok dan rak.

Penelitian ini merupakan percobaan yang dilakukan di dalam ruang terkontrol dan rancangan lingkungan dalam penelitian ini menggunakan Rancangan Acak Lengkap (RAL) faktor tunggal dengan konsentrasi BAP sebagai perlakuan (treatment) sebanyak 5 taraf yaitu : $\mathrm{b}_{1}=$ BAP $2 \mathrm{mg} / \mathrm{l}, \mathrm{b}_{2}=\mathrm{BAP} 3 \mathrm{mg} / \mathrm{l}, \mathrm{b}_{3}=\mathrm{BAP}$ $4 \mathrm{mg} / \mathrm{l}, \mathrm{b}_{4}=$ BAP $5 \mathrm{mg} / \mathrm{l}, \mathrm{b}_{5}=$ BAP $6 \mathrm{mg} / \mathrm{l}$. Perlakuan berbagai konsentrasi BAP terdapat 5 perlakuan dengan 4 kali ulangan, sehingga terdapat 20 satuan percobaan. Setiap satuan percobaan terdiri dari 2 eksplan sebagai sampel. Peubah yang diamati pada penelitian ini adalah persentase tumbuh (\%), persentase terbentuknya tunas (\%), persentase terbentuknya akar $(\%)$ dan jumlah daun (helai).

\section{HASIL DAN PEMBAHASAN}

\section{Hasil}

Persentase Tumbuh (\%)

Berdasarkan data pengamatan persentase tumbuh didapat bahwa data tidak dapat dianalisis menggunakan analisis sidik ragam dan uji lanjutan, sehingga hanya dilakukan interpretasi data 
menggunakan statistik deskriptif. Rata-rata

persentase tumbuh disajikan pada Tabel 1 .

Tabel 1. Rata-rata persentase tumbuh tanaman pisang pada berbagai konsentrasi BAP secara in vitro

\begin{tabular}{cc}
\hline Konsentrasi BAP & Rata-rata persentase tumbuh $(\%)$ \\
\hline $2 \mathrm{mg} / \mathrm{l}\left(\mathrm{b}_{1}\right)$ & 62.5 \\
$3 \mathrm{mg} / \mathrm{l}\left(\mathrm{b}_{2}\right)$ & 50 \\
$4 \mathrm{mg} / \mathrm{l}\left(\mathrm{b}_{3}\right)$ & 50 \\
$5 \mathrm{mg} / \mathrm{l}\left(\mathrm{b}_{4}\right)$ & 50 \\
$6 \mathrm{mg} / \mathrm{l}\left(\mathrm{b}_{5}\right)$ & 62.5 \\
\hline
\end{tabular}

Keterangan : data tidak dapat diolah karena tidak memenuhi kaidah statistik

Tabel 1 memperlihatkan bahwa ratarata persentase tumbuh terjadi perbedaan pada perlakuan $b_{1}$ dengan perlakuan $b_{2}, b_{3}$, dan $b_{4}$. Perlakuan $b_{1}$ dan $b_{5}$ memiliki persentase tumbuh yang sama yaitu $62.5 \%$, perlakuan $b_{2}, b_{3}$, dan $b_{4}$ juga memiliki persentase tumbuh yang sama yaitu $50 \%$. Persentase tumbuh terbanyak terdapat pada perlakuan $b_{1}$ dan $b_{5}$.

\begin{abstract}
Persentase Terbentuknya Tunas (\%)
Berdasarkan data pengamatan persentase terbentuknya tunas didapat bahwa data tidak dapat dianalisis menggunakan analisis sidik ragam dan uji lanjutan, sehingga hanya dilakukan interpretasi data menggunakan statistik deskriptif. Rata-rata persentase terbentuknya tunas disajikan pada Tabel 2 .
\end{abstract}

Tabel 2. Rata-rata persentase terbentuknya tunas tanaman pisang pada umur 3, 5, 7, 9 dan 11 MST pada berbagai konsentrasi BAP secara in vitro

\begin{tabular}{cccccc}
\hline Konsentrasi BAP & \multicolumn{5}{c}{ Rata-rata persentase terbentuknya tunas (\%) } \\
\cline { 2 - 6 } & $3 \mathrm{MST}$ & $5 \mathrm{MST}$ & $7 \mathrm{MST}$ & $9 \mathrm{MST}$ & $11 \mathrm{MST}$ \\
\hline $2 \mathrm{mg} / \mathrm{l}\left(\mathrm{b}_{1}\right)$ & 50 & 25 & 12.5 & 12.5 & 12.5 \\
$3 \mathrm{mg} / \mathrm{l}\left(\mathrm{b}_{2}\right)$ & 25 & 25 & 25 & 25 & - \\
$4 \mathrm{mg} / \mathrm{l}\left(\mathrm{b}_{3}\right)$ & 12.5 & 12.5 & 12.5 & 12.5 & 12.5 \\
$5 \mathrm{mg} / \mathrm{l}\left(\mathrm{b}_{4}\right)$ & - & - & - & - & - \\
$6 \mathrm{mg} / \mathrm{l}\left(\mathrm{b}_{5}\right)$ & 25 & 25 & 12.5 & - & - \\
\hline
\end{tabular}

Keterangan: data tidak dapat diolah karena tidak memenuhi kaidah statistik

Dari Tabel 2 memperlihatkan bahwa ratarata persentase terbentuknya tunas pada perlakuan $b_{1}$ mengalami penurunan pada umur 3 dan 5 MST, perlakuan $\mathrm{b}_{2}$ mengalami penurunan pada umur 9 MST, dan perlakuan $\mathrm{b}_{5}$ mengalami penurunan pada umur 5 MST dan 7 MST, sedangkan pada perlakuan $b_{3}$ tidak mengalami penurunan ataupun peningkatan terbentuknya tunas dan perlakuan $b_{4}$ tidak ada eksplan yang bertunas.

Persentase Terbentuknya Akar (\%)

Hasil pengamatan yang dilakukan menunjukkan bahwa pemberian berbagai konsentrasi BAP pada media belum mampu untuk memacu pembentukan akar pada eksplan, sehingga peubah persentase terbentuknya akar tidak dapat dilakukan analisis ragam.

Jumlah Tunas (buah)

Berdasarkan data pengamatan jumlah tunas didapat bahwa data tidak dapat dianalisis menggunakan analisis sidik ragam dan uji lanjutan, sehingga hanya dilakukan interpretasi data menggunakan statistik deskriptif. Rata-rata jumlah tunas disajikan pada Tabel 3. 
Tabel 3. Rata-rata jumlah tunas tanaman pisang pada berbagai konsentrasi BAP secara in vitro

\begin{tabular}{cc}
\hline Konsentrasi BAP & Rata-rata jumlah tunas (buah) \\
\hline $2 \mathrm{mg} / \mathrm{l}\left(\mathrm{b}_{1}\right)$ & 2.5 \\
$3 \mathrm{mg} / \mathrm{l}\left(\mathrm{b}_{2}\right)$ & - \\
$4 \mathrm{mg} / \mathrm{l}\left(\mathrm{b}_{3}\right)$ & 0.625 \\
$5 \mathrm{mg} / \mathrm{l}\left(\mathrm{b}_{4}\right)$ & - \\
$6 \mathrm{mg} / \mathrm{l}\left(\mathrm{b}_{5}\right)$ & - \\
\hline
\end{tabular}

Keterangan: data tidak dapat diolah karena tidak memenuhi kaidah statistik.

Dari Tabel 3 memperlihatkan bahwa rata-rata jumlah tunas pada perlakuan $b_{1}$ yaitu 2.5 buah, kemudian perlakuan $\mathrm{b}_{3}$ sebanyak 0.625 buah, sedangkan pada perlakuan $b_{2}, b_{4}$ dan $b_{5}$ tidak ada eksplan yang memiliki tunas.

Jumlah Daun (helai)

Hasil pengamatan yang dilakukan sampai dengan 13 MST menunjukkan bahwa tidak ada daun yang terbentuk, jadi peubah jumlah daun tidak dapat dilakukan analisis ragam.

\section{Pembahasan}

Hasil penelitian menunjukkan bahwa rata-rata persentase tumbuh terjadi perbedaan antara perlakuan $b_{1}$ dengan perlakuan $b_{2}, b_{3}$, dan $b_{4}$, dan juga peningkatan konsentrasi BAP yang diberikan tidak memperlihatkan pengaruh terhadap persentase tumbuh eksplan pisang. Hal ini diduga karena setelah pengkulturan eksplan pisang terjadi browning. Browning atau pencoklatan disebabkan oleh senyawa fenol yang dikeluarkan dari eksplan dan adanya gen B. Senyawa ini menghambat eksplan untuk menyerap BAP yang diberikan sehingga menyebabkan peningkatan konsentrasi BAP tidak berpengaruh.

Di samping itu, tidak berpengaruhnya peningkatan konsentrasi BAP yang diberikan diduga karena terjadi kontaminasi. Menurut Santoso \& Nursandi (2001) fenomena kontaminasi sangat beragam, keragaman tersebut dapat dilihat dari jenis kontaminannya, waktu terjadinya, dan asal terjadinya kontaminasi (media atau eksplan). Kontaminasi yang terjadi dalam perbanyakan secara in vitro akan menyebabkan tidak mampunya eksplan untuk tumbuh. Kontaminasi dapat disebabkan oleh eksplan itu sendiri atau dari faktor lingkungan.

Berdasarkan hasil penelitian terlihat bahwa rata-rata persentase terbentuknya tunas terjadi perbedaan yang cukup signifikan. Dari data persentase terbentuknya tunas terlihat pada perlakuan $b_{1}$ mengalami penurunan pada umur 3 dan $5 \mathrm{MST}$, perlakuan $\mathrm{b}_{2}$ mengalami penurunan pada umur 9 MST, dan perlakuan $\mathrm{b}_{5}$ mengalami penurunan pada umur 5 dan 7 MST. Pada perlakuan $b_{3}$ persentase terbentuknya tunas tidak mengalami penurunan atau pun peningkatan, sedangkan pada perlakuan $\mathrm{b}_{4}$ tidak ada eksplan yang bertunas. Penurunan persentase terbentuknya tunas diduga karena eksplan tersebut mengalami penurunan dalam penyerapan unsur hara, air dan BAP (sitokinin) yang diberikan. Menurut Wattimena (1988) dalam Rainiyati (2010) bahwa sitokinin berperan dalam memacu pertumbuhan dan perkembangan tanaman, khususnya tunas adventif. Jadi diduga karena adanya penurunan dalam penyerapan BAP (sitokinin) mengakibatkan menurunnya pertumbuhan dan perkembangan tunas adventif. Adanya eksplan yang mati ini diduga disebabkan oleh pencoklatan (browning) dan kontaminasi.

Hasil pengamatan persentase terbentuknya akar yang dilakukan menunjukkan bahwa pemberian berbagai konsentrasi BAP pada media belum mampu untuk memacu pembentukan akar pada eksplan, sehingga parameter persentase terbentuknya akar tidak dapat dilakukan analisis ragam. Peningkatan konsentrasi BAP yang diuji merupakan penghambat terbentunya akar. Hal ini sesuai dengan 
pendapat Wetherell (1982) dalam Surono \& Himawan (2010) bahwa sitokinin mempunyai dua peran penting yaitu merangsang pembelahan sel serta pembentukan dan perbanyakan tunas aksilar dan tunas adventif. Disamping itu Rainiyati, et., al. (2009) menambahkan bahwa terhambatnya pembentukan akar pada eksplan diduga karena zat pengatur tumbuh yang diberikan maupun yang tersedia di dalam eksplan belum mencapai rasio dan konsentrasi yang tepat sehingga belum efektif untuk menginduksi terjadinya morfogenesis berupa pembentukan akar.

Berdasarkan interpretasi data menggunakan statistik deskriptif bahwa rata-rata jumlah tunas terjadi perbedaan. Hanya perlakuan $b_{1}$ dan $b_{3}$ yang memiliki tunas. Eksplan pada perlakuan $b_{2}, b_{4}$ dan $b_{5}$ tidak bisa diamati karena eksplan mati. Hal ini diduga disebabkan oleh pencoklatan (browning) dan kontaminasi.

Hasil pengamatan jumlah daun yang dilakukan pada umur 13 MST menunjukkan bahwa tidak ada daun yang terbentuk karena proses penambahan jumlah dan panjang tunas masih berjalan, jadi parameter jumlah daun tidak dapat dilakukan analisis ragam.

\section{KESIMPULAN}

Berdasarkan hasil penelitian, maka dapat diambil kesimpulan pemberian berbagai konsentrasi BAP menentukan pertumbuhan tanaman pisang kepok secara in vitro dan $2 \mathrm{mg} / \mathrm{l}$ BAP merupakan konsentrasi yang paling baik untuk pertumbuhan tanaman pisang kepok secara in vitro.

\section{DAFTAR PUSTAKA}

Dinas Pertanian Tanaman Pangan dan Hortikultura Kabupaten Hulu Sungai Utara. 2012. Produksi Tanaman Pisang di Kabupaten Hulu Sungai Utara. Amuntai.

Hanafiah, K. A. 2002. Rancangan Percobaan. Rajawali Pers. Palembang.
Luqman. 2012. Makalah Kultur Pisang. http://luqmanmaniabgt.blogspot.co

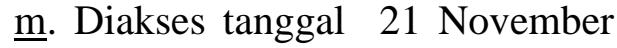
2012.

Rainiyati. 2010. Pertumbuhan dan perkembangan nodul pisang (Musa $A A B$ Raja Nangka) secara in vitro. Percikan 112.

Rainiyati, Lizawati dan M. Kristiana. 2009. Peranan IAA dan BAP terhadap perkembangan nodul pisang (Musa $\mathrm{AAB}$ ) raja nangka secara in vitro. Jurnal Agronomi Vol. 13 No. 01.

Santoso, U dan F. Nursandi. 2001. Kultur Jaringan Tanaman. Universitas Muhammadiyah Malang. Malang.

Sitohang, N. 2006. Multiplikasi propagula pisang barangan (Musa paradisiaca L.) dari berbagai jumlah tunas, dalam media MS yang diberi BAP pada berbagai konsentrasi. Jurnal Penelitian Budidaya Ilmu Pertanian 4 (1).

Surono, A. dan A. Himawan. 2010. Multiplikasi tunas pisang ambon secara in vitro dengan menggunakan medium murashige dan skoog dengan penambahan hormon benzylaminopurin dan kinetin. Laporan Penelitian CV. Agribiotec. 